\title{
EXTRACTION OF TANNINS AND SAPONINS FROM PLANT SOURCES AND THEIR EFFECTS ON In vitro METHANOGENESIS AND RUMEN FERMENTATION
}

\author{
P. Yuliana ${ }^{1}$, E.B. Laconi ${ }^{1}$, E. Wina ${ }^{2}$ and A. Jayanegara ${ }^{1}$ \\ ${ }^{1}$ Faculty of Animal Science, Bogor Agricultural University, \\ Jl. Agatis, Darmaga Campus, Bogor 16680 - Indonesia \\ ${ }^{2}$ Indonesian Research Center for Animal Production, Ciawi, Bogor 16002 - Indonesia \\ Corresponding E-mail: anu_jayanegara@yahoo.com \\ Received March 26, 2014; Accepted May 14, 2014
}

\begin{abstract}
ABSTRAK
Penelitian ini bertujuan untuk mengekstrak tanin dari daun mahoni (Swietenia mahagony) dan saponin dari buah lerak (Sapindus rarak) menggunakan sejumlah pelarut, serta mengamati efek penambahan ekstrak terhadap fermentasi rumen dan metanogenesis secara in vitro. Pelarut yang digunakan untuk ekstraksi adalah air, metanol, aseton dan kombinasinya. Ekstrak tanin dan saponin ditambahkan pada botol inkubasi yang mengandung rumput Brachiaria humidicola dan legum Indigofera sp. (1:1 w/w) dengan perlakuan sebagai berikut (dalam empat ulangan): R1: kontrol, R2: R1 + 0,5 mg/mL ekstrak tanin, R3: R1 + $1 \mathrm{mg} / \mathrm{mL}$ ekstrak tanin, R4: R1 + 0,5 mg/mL ekstrak saponin, R5: $\mathrm{R} 1+1 \mathrm{mg} / \mathrm{mL}$ ekstrak saponin, $\mathrm{R} 6: \mathrm{R} 1+0,5 \mathrm{mg} / \mathrm{mL}$ ekstrak tanin $+0.5 \mathrm{mg} / \mathrm{mL}$ ekstrak saponin, dan R7: R1 $+1 \mathrm{mg} / \mathrm{mL}$ ekstrak tanin $+1 \mathrm{mg} / \mathrm{mL}$ ekstrak saponin. Hasil menunjukkan bahwa $75 \%$ air $+25 \%$ metanol merupakan pelarut terbaik untuk mengekstrak tanin dari daun mahoni sedangkan $100 \%$ metanol adalah yang terbaik untuk mengekstrak saponin dari buah lerak. Produksi gas tertinggi dan penurunan gas metana terbaik didapatkan dari perlakuan R7. Sebagai kesimpulan, kombinasi ekstrak tanin dan saponin berpotensi untuk menurunkan emisi metana dari rumen.
\end{abstract}

Kata kunci: tanin, saponin, metana, rumen, in vitro

\begin{abstract}
This study was aimed to extract tannins from Swietenia mahagony and saponins from Sapindus rarak by using different solvents, and to test their extracts on in vitro rumen fermentation and methanogenesis. Solvents used for extraction were water, methanol, acetone and their combinations. Tannin and saponin extracts were added into each incubation bottle containing Brachiaria humidicola grass and Indigofera sp. legume $(1: 1 \mathrm{w} / \mathrm{w})$ according to the following treatments (in four replicates): R1: control substrate, R2: R1 $+0.5 \mathrm{mg} / \mathrm{ml}$ tannin extract, R3: R1 $+1 \mathrm{mg} / \mathrm{mL}$ tannin extract, R4: R1 + 0.5 $\mathrm{mg} / \mathrm{mL}$ saponin extract, R5: R1 $+1 \mathrm{mg} / \mathrm{mL}$ saponin extract, R6: $\mathrm{R} 1+0.5 \mathrm{mg} / \mathrm{mL}$ tannin extract +0.5 $\mathrm{mg} / \mathrm{mL}$ saponin extract, and R7: R1 $+1 \mathrm{mg} / \mathrm{mL}$ tannin extract $+1 \mathrm{mg} / \mathrm{mL}$ saponin extract. Results revealed that $75 \%$ water $+25 \%$ methanol was the best solvent to extract tannins from $S$. mahagony whereas $100 \%$ methanol was the best to extract saponins from $S$. rarak. The highest gas production and the lowest methane emission were obtained in R7. It can be concluded that combination of tannin and saponin extracts were potential in mitigating ruminal methane emissions.
\end{abstract}

Keywords: tannin, saponin, methane, rumen, in vitro

\section{INTRODUCTION}

Methane $\left(\mathrm{CH}_{4}\right)$ is the second largest contributor of greenhouse gases after $\mathrm{CO}_{2}$ in the atmosphere. Despite the fact, the ability of methane to retain heat is 21 times bigger than that 
of $\mathrm{CO}_{2}$. Ruminant livestock in particular is one of the contributors to the anthropogenic methane gas accumulation which is about $28 \%$ of the total methane (Beauchemin et al., 2008). In addition to its impact on global warming, methane emission from ruminants is also a form of energy loss that would otherwise be used to support productivity; the amount of energy loss from ruminants is approximately $8-14 \%$ from the digestible energy intake (Cottle et al., 2011).

An approach for mitigating methane emission from ruminants is through feeding strategy. A number of attempts have been conducted and shown to be effective in decreasing the methane emission (Cottle et al., 2011). Accordingly, natural compounds are preferred especially after the ban of using antibiotics as feed additives in many countries. Plants of tropical origin are generally high in plant secondary compounds such as polyphenols (tannins) and saponins. Plants containing tannins and saponins can be used for mitigating enteric methane emission (Jayanegara et al., 2013; 2014). However, there were limited studies that attempted to extract the compounds from plant sources and to further examine their effects on methane emission. Moreover, although some studies have tested such effects of tannins or saponins individually, none of them have combined both tannins and saponins simultaneously. It would be of interest to investigate whether the compounds interact each other, either synergistically or antagonistically, in mitigating methane emission or no interaction at all (additive effect only).

This study was aimed to extract tannins from Swietenia mahagony and saponins from Sapindus rarak by using different solvents. Subsequently, both extracts were tested using in vitro rumen fermentation system to observe their effects of rumen fermentation and methanogenesis.

\section{MATERIALS AND METHODS}

\section{Extraction Procedures}

The leaves of $S$. mahagony (source of tannins) and the fruits of $S$. rarak (source of saponins) were oven-dried at $50{ }^{\circ} \mathrm{C}$ for $12 \mathrm{~h}$, and then ground to pass a $0.5 \mathrm{~mm}$ sieve. The materials were subjected to various solvent extractions, i.e. $100 \%$ water $(\mathrm{P} 1), 75 \%$ water $+25 \%$ methanol (P2), 50\% water $+50 \%$ methanol (P3), 25\% water
+ 75\% methanol (P4), 100\% methanol (P5), 75\% water $+25 \%$ acetone (P6), $50 \%$ water $+50 \%$ acetone $(\mathrm{P} 7), 25 \%$ water $+75 \%$ acetone $(\mathrm{P} 8)$, and $100 \%$ acetone (P9).

For extraction and quantification of tannins in $S$. mahagony, $10 \mathrm{~mL}$ of each solvent was inserted into a test tube containing $500 \mathrm{mg}$ of the sample, then put into a beaker glass that was filled with water. The tube was then placed in an ultrasonic water bath (Barnstead/Lab Line Aqua Wave 9377, E60H, Germany) and extracted for 20 min at room temperature. Each sample was centrifuged (Thermo Scientific IEC Centra CL2 Centrifuge, Fisher Scientific Pte Ltd, Singapore) at $4^{\circ} \mathrm{C}$ for $10 \mathrm{~min}$; this procedure was repeated twice and the supernatants were combined. Total phenols (TP) and total tannins (TT) were measured according to Makkar (2003) by employing Folin-Ciocalteu method. Polyvinyl polypyrrolidone (PVPP) was used to separate tannin phenols from non-tannin phenols. The absorbance was read by using a UV-Vis spectrophotometer (UV-Vis spectrophotometer, U1800, 5930482, High Technology Corporation, Tokyo, Japan) with a wavelength of $724 \mathrm{~nm}$.

For extraction and quantification of saponins in $S$. rarak, $10 \mathrm{~mL}$ of each solvent was inserted into a test tube containing $500 \mathrm{mg}$ of the sample, then put into a beaker glass that was filled with water. The tube was then placed in an ultrasonic water bath (Barnstead/Lab Line Aqua Wave 9377, $\mathrm{E} 60 \mathrm{H}$, Germany) and extracted for $20 \mathrm{~min}$ at room temperature. Each sample was centrifuged (Thermo Scientific IEC Centra CL2 Centrifuge, Fisher Scientific Pte Ltd, Singapore) at $4^{\circ} \mathrm{C}$ for 10 $\mathrm{min}$; this procedure was repeated twice and the supernatants were combined. Analysis of total saponins was performed according to Hiai and Nakajima (1976) and calibrated against Diosgenin standard (Sigma-Aldrich D1634, Sigma Aldrich Chemie GmbH, Steinheim, Germany). The sample was added with $0.2 \mathrm{~mL}$ vanillin, $0.25 \mathrm{~mL}$ ethanol and $2.5 \mathrm{~mL} 72 \% \mathrm{H}_{2} \mathrm{SO}_{4}$, and then vortexed. The sample was heated in a water bath (Watson Victor Ltd., Bw6t, Watson Victor Limited, New Zealand) at $60^{\circ} \mathrm{C}$ for $10 \mathrm{~min}$. After being cool, the absorbance was read in UV-Vis spectrophotometer (UV-Vis spectro-photometer, U-1800, 5930482, High Technology Corporation, Tokyo, Japan) with a wavelength of $544 \mathrm{~nm}$.

The solvents resulted in the highest tannin and saponin concentrations were further used for the in vitro rumen fermentation experiment. The 
organic solvent was removed by using a rotary evaporator (Buchi Rotavapor R-200, Germany) followed by freeze drying (lyophilization) for 24 $\mathrm{h}$ to obtain dry extracts of tannins and saponins.

\section{In Vitro Rumen Fermentation Procedures}

Substrate used in this study was a mixture of Brachiaria humidicola grass and Indigofera sp. legume. Both materials were dried at $50{ }^{\circ} \mathrm{C}$ for 12 $\mathrm{h}$, ground to pass a $1 \mathrm{~mm}$ sieve and homogeneously mixed in the same ratio (DM basis). Chemical composition of the basal substrate is presented in Table 1.

The in vitro incubation was conducted by the method of Theodorou and Brooks (1990). Briefly, one gram of substrate was added into each incubation bottle. Rumen fluid was taken from two fistulated Friesian-Holstein cows before morning feeding, and then brought to the laboratory to be filtered and mixed with buffer solution (rumen fluid:buffer $=1: 4 \mathrm{v} / \mathrm{v}$ ). The buffer solution was comprised of $385.6 \mathrm{~mL}$ bicarbonate, $193.6 \mathrm{~mL}$ macro minerals, $0.256 \mathrm{~mL}$ micro minerals, $0.975 \mathrm{~mL}$ resazurine, $36.8 \mathrm{~mL}$ reducing solution and $579 \mathrm{~mL}$ distilled water. Rumenbuffer solution was saturated with $\mathrm{CO}_{2}$ during the mixing process. Similarly, the incubation bottles were saturated with $\mathrm{CO}_{2}$ before closing in order to ensure the anaerobic condition. An amount of 100 $\mathrm{mL}$ rumen-buffer solution was added into each incubation unit. Tannin and saponin extracts were added into each incubation bottle according to the following treatments: R1: control substrate, R2: $\mathrm{R} 1+0.5 \mathrm{mg} / \mathrm{mL}$ tannin extract, R3: R1 + 1 $\mathrm{mg} / \mathrm{mL}$ tannin extract, R4: R1 $+0.5 \mathrm{mg} / \mathrm{mL}$ saponin extract, R5: R1 $+1 \mathrm{mg} / \mathrm{mL}$ saponin extract, R6: R1 $+0.5 \mathrm{mg} / \mathrm{mL}$ tannin extract +0.5 $\mathrm{mg} / \mathrm{mL}$ saponin extract, and $\mathrm{R} 7: \mathrm{R} 1+1 \mathrm{mg} / \mathrm{mL}$ tannin extract $+1 \mathrm{mg} / \mathrm{mL}$ saponin extract. The incubation bottles were then immediately closed with rubber caps. The bottles were incubated in a water bath at $39^{\circ} \mathrm{C}$ for $48 \mathrm{~h}$.

Total gas production was recorded at 4, 6, 9, $12,24,30,36$, and $48 \mathrm{~h}$ after incubation by using a gas syringe (Sigma-Aldrich Z314382-1EA, Poulten and Graf GmbH, Wertheim, Germany) equipped with an injected needle (BD REF Precision Glide Needle TM 302 008, Singapore). Measurement of methane production was conducted based on Fievez et al. (2005). Total gas produced was flown into $5 \mathrm{~N} \mathrm{NaOH}$. Carbon dioxide, the main gas produced during in vitro rumen fermentation, was bound by $\mathrm{NaOH}$ and
Table 1. Nutrients Composition in Feed as Substrate (in \% Dry Matter)

\begin{tabular}{lccc}
\hline Nutrients & $\begin{array}{c}\text { Brachiaria } \\
\text { humidicola }\end{array}$ & Indigofera $\mathrm{sp}$. & $\mathrm{BH}: \mathrm{I}$ \\
\hline $\mathrm{CP}$ & 7.15 & 25.60 & 16.38 \\
$\mathrm{EE}$ & 1.25 & 2.51 & 1.88 \\
$\mathrm{NDF}$ & 82.14 & 53.66 & 67.90 \\
$\mathrm{ADF}$ & 38.04 & 49.05 & 43.55 \\
Lignin & 3.82 & 19.49 & 11.66 \\
GE & 4366 & 3579 & 3973 \\
\hline
\end{tabular}

BH:I, Brachiaria humidicola:Indigofera sp. (1:1 w/w); CP: crude protein; EE: ether extract; NDF: neutral detergent fiber; ADF: acid detergent fiber; GE: gross energy

methane volume was read in another syringe connected to the system.

\section{Statistical Analysis}

The experiment on extraction of tannins and saponins was based on a completely randomized design, and each treatment was performed in three replicates. The experiment on in vitro rumen fermentation employed a randomized complete block design with four replicates, and each replicate was represented by two incubation bottles. Different batches of rumen fluid (runs) served as the block. Data obtained from both experiments were analyzed by analysis of variance (ANOVA). When a parameter showed significantly different at $\mathrm{P}<0.05$ for various experimental treatments, Duncan's multiple range test was conducted for comparison among treatment means. All of the statistical analyses were performed by using SPSS statistical software version 16.0.

\section{RESULTS AND DISCUSSION}

\section{Extraction of Tannins and Saponins}

Total phenol and total tannin contents of $S$. mahagony leaves extracted with various solvents are presented in Table 2. Total tannins were highest when extracted with a mixture of solvents, i.e. $25 \%$ water $+75 \%$ methanol. Total phenol contents were also high when extracted with the solvent mixture. Apparently the compounds could 
not be extracted optimally by using a single solvent only like water, methanol or acetone. Chemical structure of tannins contains both polar (hydrophilic) and non-polar (hydrophobic) groups; hydroxyl groups are polar and the aromatic phenolic structures are non-polar (Mueller-Harvey, 2006). Therefore, for extraction of tannins, mixtures of polar and less polar solvents are required. Mixture of water and methanol represented polar and less polar solvents, respectively. However, Makkar (2003) recommended the use of $30 \%$ water $+70 \%$ acetone to extract tannins from various plants sources. Apparently generalization of a certain optimum solvent composition to extract tannins from different plant sources was uneasy since tannins are quite a diverse chemical structure (Mueller-Harvey, 2006) and, hence, their chemical properties may differ from one to another. For instance, Iqbal et al. (2012) found that the use of high polarity solvent, i.e. methanol improved the recovery of total phenols in the extract. Further, the author stated that the efficiency of different solvents for phenols extraction was (ordered from highest to lowest): methanol $>$ water $>$ ethanol $>$ acetone $>$ chloroform $>$ hexane.

Total saponin contents of $S$. rarak fruits extracted with various solvents are presented in Table 3. The best solvent to extract saponins from the fruits was $100 \%$ methanol; the yield of total saponins of $S$. rarak fruits extracted using $100 \%$ methanol was higher by about two fold as compared to the other solvents $(\mathrm{P}<0.05)$. Although chemical structure of saponins contains both polar (glycone) and non-polar (sapogenin) groups (Wina et al., 2005), it seems that extraction of saponins did not need mixture of solvents like tannins. Based on these results, therefore, the respective solvents were used to extract the contents of tannins or saponins from $S$. mahagony and $S$. rarak for the subsequent in vitro rumen fermentation experiment.

\section{Methanogenesis and Rumen Fermentation}

Total gas production by addition of tannin and/or saponin extracts to basal substrate is presented in Figure 1. Addition of tannins and/or saponin extracts had no significant effects on total gas production at various time point intervals. Gas produced by rumen microbes during incubation partly was a product of microbial metabolism to digest and ferment feed or substrate, and also as a result of the buffering effect of artificial saliva (buffer solution) when the volatile fatty acids were produced (Getachew et al., 1998). Such

Table 2. Total Phenol (TP) and Total Tannin (TT) Contents of Swietenia mahagony Leaves Extracted by Various Solvents $(\mathrm{n}=3)$

\begin{tabular}{clcc} 
Treatment & \multicolumn{1}{c}{ Solvent } & TP $(\% \mathrm{DM})$ & TT $(\% \mathrm{DM})$ \\
\hline P1 & $100 \%$ water & $26.6^{\mathrm{b}}$ & $19.0^{\mathrm{b}}$ \\
P2 & $75 \%$ water $+25 \%$ methanol & $30.4^{\mathrm{bc}}$ & $22.0^{\mathrm{bc}}$ \\
P3 & $50 \%$ water $+50 \%$ methanol & $31.7^{\mathrm{bcd}}$ & $18.2^{\mathrm{b}}$ \\
P4 & $25 \%$ water $+75 \%$ methanol & $41.6^{\mathrm{de}}$ & $29.9^{\mathrm{c}}$ \\
P5 & $100 \%$ methanol & $31.0^{\mathrm{bcd}}$ & $17.1^{\mathrm{b}}$ \\
P6 & $75 \%$ water $+25 \%$ acetone & $43.1^{\mathrm{e}}$ & $26.7^{\mathrm{bc}}$ \\
P7 & $50 \%$ water $+50 \%$ acetone & $39.0^{\mathrm{cde}}$ & $25.7^{\mathrm{bc}}$ \\
P8 & $25 \%$ water $+75 \%$ acetone & $39.9^{\mathrm{cde}}$ & $26.9^{\mathrm{bc}}$ \\
P9 & $100 \%$ acetone & $3.7^{\mathrm{a}}$ & $2.3^{\mathrm{a}}$ \\
& SEM & 0.92 & 1.76 \\
& P-Value & $<0.001$ & $<0.001$
\end{tabular}

Different superscripts in the same column are significantlydifferent at $\mathrm{P}<0.05 ;$ DM: dry matter; SEM: standard error of the mean 
Table 3. Total Saponin Contents of Sapindus rarak Fruits Extracted by Various Solvents $(\mathrm{n}=3)$

\begin{tabular}{ccc}
\hline Treatment & Solvent & $\begin{array}{c}\text { Total } \\
\text { saponins } \\
(\% \mathrm{DM})\end{array}$ \\
\hline P1 & $100 \%$ water & $19.6^{\mathrm{b}}$ \\
P2 & $75 \%$ water $+25 \%$ methanol & $22.6^{\mathrm{b}}$ \\
P3 & $50 \%$ water $+50 \%$ methanol & $23.4^{\mathrm{b}}$ \\
P4 & $25 \%$ water $+75 \%$ methanol & $22.5^{\mathrm{b}}$ \\
P5 & $100 \%$ methanol & $44.1^{\mathrm{c}}$ \\
P6 & $75 \%$ water $+25 \%$ acetone & $20.4^{\mathrm{b}}$ \\
P7 & $50 \%$ water $+50 \%$ acetone & $18.8^{\mathrm{b}}$ \\
P8 & $25 \%$ water $+75 \%$ acetone & $24.0^{\mathrm{b}}$ \\
P9 & $100 \%$ acetone & $12.6^{\mathrm{a}}$ \\
& SEM & 3.30 \\
& P-Value & $<0.001$ \\
\hline
\end{tabular}

Different superscripts in the same column are significantly at $\mathrm{P}<0.05$; DM: dry matter; SEM: standard error of the mean

results may suggest that the addition of tannin (from $S$. mahagony) and/or saponin (from $S$. rarak) extracts at a level of 0.5 or $1.0 \mathrm{mg} / \mathrm{mL}$ did not impair rumen fermentation. This was confirmed by the other rumen fermentation parameters, i.e. dry matter digestibility (DMD), organic matter digestibility (OMD), bacteria and protozoa population, and ammonia concentration, which were not significantly different from control (Table 4). Kinetics of methane concentration (\%) in gas total is shown in Figure 2. In general, all treatments increased methane concentration during early incubation and then began to decline after $8 \mathrm{~h}$ and stabilized after 24 h. Apparently methanogens were more active during early incubation and less active as the fermentation substrate was depleted. The addition of $S$. mahagony and $S$. rarak extracts either single (R2-R5) or in combination (R6-R7) tended to decrease methane concentration as compared to control treatment (R1) at $48 \mathrm{~h}$. The best treatment in lowering methane was shown by R7 (combination of tannin and saponin extracts at 1 $\mathrm{mg} / \mathrm{mL}$ ) which decreased the methane concentration by approximately $17 \%$.
Dry matter digestibility (DMD) and organic matter digestibility (OMD) did not differ significantly among all treatments as shown in Table 4. Digestibility of nutrients can determine the quality of the feed. The higher the digestibility of a feed, the higher the chance of nutrient in the feed to be utilized by livestock. This was in agreement with a study reported that saponin extracts or plant containing saponins did not affect digestibility (Hess et al., 2003), but decrease methane production (Santoso et al., 2004). The addition of tannin extracts (R2-R3) numerically decreased digestibility of substrate since tannins exert anti-microbial actions in the rumen (Patra and Saxena, 2009), which may show adverse effects on rumen fermentation and digestion of feeds. Tannin and saponin extracts addition did not alter $\mathrm{N}-\mathrm{NH}_{3}$ concentration as compared to the control treatment. The range of $\mathrm{N}^{-\mathrm{NH}_{3}}$ in the present study was between 24.92 to $30.89 \mathrm{mM}$, which was slightly above the optimum concentration to support microbial protein synthesis according to McDonald et al. (2002), i.e. $6-21 \mathrm{mM}$.

The addition of tannin and saponin extracts either in single or in combination tended to decrease rumen protozoa population; the best treatment was shown by R7. The existence of protozoa in rumen often disrupts the bacteria ecosystem because they have predatory activities against the bacteria. In addition, the presence of protozoa affects methanogens in the rumen since parts of the methanogens are in symbiosis with protozoa. Saponins may reduce methane emissions through elimination of rumen protozoa population due to the capacity of saponins in binding the sterol present in protozoa cell membrane, causing the cell lysis (Wina et al., 2005; Beauchemin et al., 2008). On the other hand, tannins act as anti-methanogenic compounds that directly influence the methanogens and indirectly by decreasing feed digestibility (Jayanegara et al., 2009; Jayanegara and Palupi, 2010) and, hence, limiting hydrogen supply for methanogenesis. Tannins also inhibit the growth of cellulolytic and proteolytic bacteria (McSweeney et al., 2001).

\section{CONCLUSION}

Extraction of tannins and saponins from plants sources was strongly influenced by the type and composition of the solvents used. The optimal solvent to extract tannins from S. mahagony 


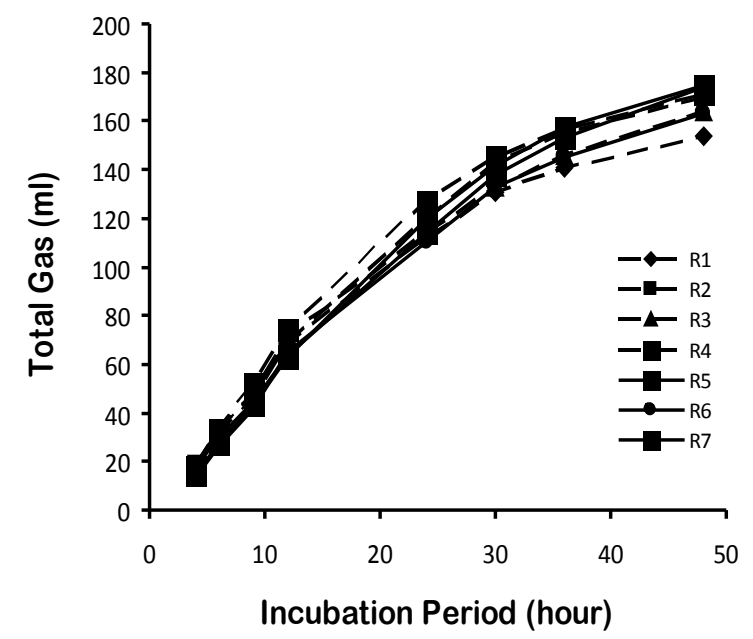

Figure 1. Total Gas Production of Added Tannin and Saponin Extracts in Subtrate when Incubated in Buffered-rumen Fluid. R1: control substrate, R2: R1 $+0.5 \mathrm{mg} / \mathrm{mL}$ tannin extract, R3: R1 + $1 \mathrm{mg} / \mathrm{mL}$ tannin extract, R4: R1 $+0.5 \mathrm{mg} / \mathrm{mL}$ saponin extract, R5: R1 + $1 \mathrm{mg} / \mathrm{mL}$ saponin extract, R6: R1 + 0.5 $\mathrm{mg} / \mathrm{mL}$ tannin extract $+0.5 \mathrm{mg} / \mathrm{mL}$ saponin extract, and R7: R1 $+1 \mathrm{mg} / \mathrm{mL}$ tannin extract $+1 \mathrm{mg} / \mathrm{mL}$ saponin extract.

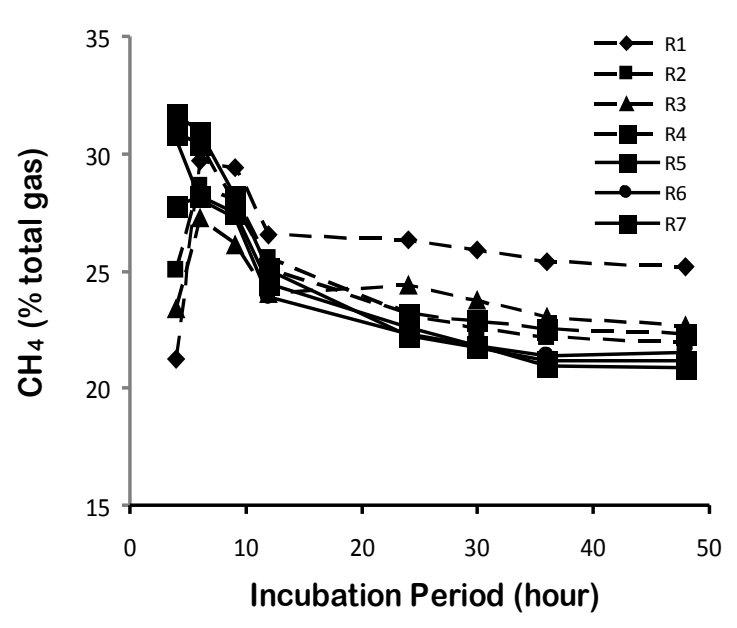

Figure 2. Methane Concentration of Added Tannin and Saponin Extracts in Subtrate when Incubated in Buffered-rumen Fluid. R1: control substrate, $\mathrm{R} 2: \mathrm{R} 1+0.5 \mathrm{mg} / \mathrm{mL}$ tannin extract, R3: R1 + 1 $\mathrm{mg} / \mathrm{mL}$ tannin extract, R4: R1 $+0.5 \mathrm{mg} / \mathrm{mL}$ saponin extract, R5: R1 $+1 \mathrm{mg} / \mathrm{mL}$ saponin extract, R6: R1 $+0.5 \mathrm{mg} / \mathrm{mL}$ tannin extract +0.5 $\mathrm{mg} / \mathrm{mL}$ saponin extract, and $\mathrm{R} 7: \mathrm{R} 1+1 \mathrm{mg} / \mathrm{mL}$ tannin extract $+1 \mathrm{mg} / \mathrm{mL}$ saponin extract.

Table 4. Dry Matter Digestibility (DMD), Organic Matter Digestibility (OMD), Microbial Population and $\mathrm{N}_{-} \mathrm{NH}_{3}$ Concentration of Added Tannin and Saponin Extracts in Subtrate when Incubated in Buffered-rumen Fluid at $48 \mathrm{~h}$

\begin{tabular}{cccccc}
\hline Treatment & $\begin{array}{c}\text { DMD } \\
\text { (\%) }\end{array}$ & $\begin{array}{c}\text { OMD } \\
(\%)\end{array}$ & $\begin{array}{c}\text { Bacteria } \\
(\log \mathrm{cfu} / \mathrm{ml})\end{array}$ & $\begin{array}{c}\text { Protozoa } \\
(\log \text { cell/ml })\end{array}$ & $\begin{array}{c}\text { N-NH } \\
(\mathrm{mM})\end{array}$ \\
\hline R1 & 67.20 & 67.10 & 10.15 & 7.17 & 30.89 \\
R2 & 64.02 & 63.79 & 9.92 & 7.08 & 26.30 \\
R3 & 53.32 & 52.62 & 10.05 & 7.11 & 27.38 \\
R4 & 59.96 & 59.39 & 9.98 & 7.15 & 25.93 \\
R5 & 51.66 & 57.75 & 9.91 & 7.10 & 24.92 \\
R6 & 64.06 & 64.79 & 9.92 & 7.15 & 25.22 \\
R7 & 59.24 & 59.15 & 9.93 & 7.03 & 25.50 \\
SEM & 1.99 & 2.19 & 0.02 & 0.02 & 0.80 \\
P-value & 0.28 & 0.60 & 0.59 & 0.07 & 0.31
\end{tabular}

R1: control substrate, $\mathrm{R} 2: \mathrm{R} 1+0.5 \mathrm{mg} / \mathrm{mL}$ tannin extract, $\mathrm{R} 3: \mathrm{R} 1+1 \mathrm{mg} / \mathrm{mL}$ tannin extract, $\mathrm{R} 4: \mathrm{R} 1+0.5$ $\mathrm{mg} / \mathrm{mL}$ saponin extract, R5: R1 $+1 \mathrm{mg} / \mathrm{mL}$ saponin extract, R6: R1 $+0.5 \mathrm{mg} / \mathrm{mL}$ tannin extract $+0.5 \mathrm{mg} / \mathrm{mL}$ saponin extract, and R7: R1 $+1 \mathrm{mg} / \mathrm{mL}$ tannin extract $+1 \mathrm{mg} / \mathrm{mL}$ saponin extract 
leaves was $25 \%$ water $+75 \%$ methanol, while $100 \%$ methanol was optimal to extract saponins from $S$. rarak fruits. The addition of tannin and saponin extracts simultaneously in the basal substrate reduced methane emissions especially when added at $1 \mathrm{mg} / \mathrm{mL}$. The treatment was able to reduce methane emission by $17 \%$ without reducing feed digestibility and ammonia concentration.

\section{REFERENCES}

Beauchemin, K.A., M. Kreuzer, F. O’Mara and T.A. McAllister. 2008. Nutritional management for enteric methane abatement: a review. Aust. J. Exp. Agric. 48:21-27.

Cottle, D.J., J.V. Nolan and S.G. Wiedemann. 2011. Ruminant enteric methane mitigation: a review. Anim. Prod. Sci. 51:491-514.

Fievez, V., O.J. Babayemi and D. Demeyer. 2005. Estimation of direct and indirect gas production in syringes: a tool to estimate short chain fatty acid production that requires minimal laboratory facilities. Anim. Feed Sci. Technol. 123-124:197-210.

Getachew, G., M. Blummel, H.P.S. Makkar and K. Becker. 1998. In vitro gas measuring techniques for assessment of nutritional quality of feeds: a review. Anim. Feed Sci. Technol. 72:261-281.

Hess, H.D., M. Kreuzer, T.E. Diaz, C.E. Lascano, J.E. Carulla, C.L. Soliva and A. Machmuller. 2003. Saponon rich tropical fruits affect fermentation and methagonesis in faunated and defaunated rumen fluid. Anim. Feed Sci. Technol. 109:79-94.

Hiai, S. and T. Nakajima. 1976. Color Reaction of some sapogenins and saponins with vanillin and sulfuric acid. Planta Med. 29:116-122.

Iqbal, S., U. Younas, K.W. Chan, M. Zia-ul-haq and M. Ismail. 2012. Chemical composition of Artemisia annua L. leaves and antioxidant potential of extracts as a function of extraction solvents. Molecules 17: 6020-6032.

Jayanegara, A., A. Sofyan, H.P.S. Makkar and K. Bekker. 2009. Kinetika produksi gas, kecernaan bahan organik dan produksi gas metana in vitro pada hay dan jerami yang disuplementasi hijauan mengandung tanin. Med. Pet. 32:120-129.

Jayanegara, A. and E. Palupi. 2010. Cendensed tannin effects on nitrogen digestion in ruminants: a meta-analysis from in vitro and in vivo studies. Med. Pet. 33:176-181

Jayanegara, A., S. Marquardt, E. Wina, M. Kreuzer and F. Leiber. 2013. In vitro indications for favourable non-additive effects on ruminal methane mitigation between high-phenolic and high-quality forages. Brit. J. Nutr. 109:615-622.

Jayanegara, A., E. Wina and J. Takahashi. 2014. Meta-analysis on methane mitigating properties of saponin-rich sources in the rumen: influence of addition levels and plant sources. Asian-Aust. J. Anim. Sci. (in press).

Makkar, H.P.S. 2003. Quantification of Tannins in Tree and Shrub Foliage: A Laboratory Manual. Kluwer Academic Publishers, Dordrecht, The Netherlands.

McDonald, P., R.A. Edwards and J.F.D. Greenhalgh. 2002. Animal Nutrition. $6^{\text {th }}$ Edition. Longman, London, UK.

McSweeney, C., B. Palmer, R. Bunch and D. Krause. 2001. Effect of the tropical forage calliandra on microbial protein synthesis and ecology in the rumen. J. Appl. Microbiol. 90:78-88.

Mueller-Harvey, I. 2006. Unravelling the conundrum of tannins in animal nutrition and health. J. Sci. Food Agric. 86:20102037.

Patra, A.K. and J. Saxena. 2009. Dietary phytochemicals as rumen modifiers: a review of the effects on microbial populations. Anton. Leeuwen. 96:363-375.

Santoso, B., B. Mwenya, C. Sar, Y. Gamo, T. Kobayashi, R. Morikawa, K. Kimura, H. Mizukoshi and J. Takahashi. 2004. Effects of supplementing galacto-oligosaccharides, Yucca schidigera and nisin on rumen methanogenesis, nitrogen and energy metabolism in sheep. Livest. Prod. Sci. 91:209-217.

Theodorou, M.K and A.E. Brooks. 1990. Evaluation of a New Procedure for Estimating the Fermentation Kinetics of Tropial Feeds The Natural Resources Institute, Chatham, UK.

Wina, E., S. Muetzel, E. Hoffman, H.P.S. Makkar and K. Becker. 2005. Saponins containing methanol extract of Sapindus rarak affect microbial fermentation, microbial activity and microbial community structure in vitro. Anim. Feed Sci. Technol. 121:159-174. 